\title{
Institutional characterisation of water clear cell parathyroid adenoma: a rare entity often unrecognised by TC-99m-sestamibi scintigraphy
}

\author{
C. Christofer Juhlin ${ }^{1,2}$, Inga-Lena Nilsson ${ }^{3,4}$, Henrik Falhammar ${ }^{4,5}$, \\ JAN ZEDENIUS ${ }^{3,4}$ \\ ${ }^{1}$ Department of Pathology and Cytology, Karolinska University Hospital, Stockholm, Sweden; \\ ${ }^{2}$ Department of Oncology-Pathology, Karolinska Institutet, Stockholm, Sweden; ${ }^{3}$ Department \\ of Breast, Endocrine Tumors and Sarcoma, Karolinska University Hospital, Stockholm, \\ Sweden; ${ }^{4}$ Department of Molecular Medicine and Surgery, Karolinska Institutet, Stockholm, \\ Sweden; ${ }^{5}$ Department of Endocrinology, Metabolism and Diabetes, Karolinska University \\ Hospital, Stockholm, Sweden
}

\begin{abstract}
Summary
Parathyroid lesions exhibiting a water clear cell morphology are exceedingly rare manifestations in primary hyperparathyroidism (PHPT), and the phenomenon has been reported both for uniglandular (water clear cell adenoma; WCCA) and multiglandular disease (water clear cell hyperplasia; WCCH). In all, only 24 previous descriptions of WCCA exist in the literature. Herein, we present seven cases with water clear cell morphology (6 WCCAs and 1 case of WCCH) in an institutional series of approximately 4000 parathyroid lesions spanning 29 years in a tertiary centre setting. Major histological attributes and clinical parameters associated with this morphological subtype were reviewed, and a literature search was conducted.

WCCA and WCHH exhibited an institutional prevalence of $0.15 \%$ and $0.025 \%$, respectively. All cases displayed histological hallmarks of water clear cell morphology, with cells exhibiting abundant cytoplasm filled with vacuoles. Atypical findings or unequivocal evidence of invasive behaviour were not observed. The gender distribution was 6:1 (F:M), patients were generally symptomatic with mild hypercalcaemia, and the median age at surgery was 53 years (range 38-78). The preoperative localisation was inconclusive in four of seven, and neck exploration of all four glands was undertaken in five cases. The excised WCCAs exhibited an average weight of $1215 \mathrm{mg}$, markedly higher than conventional adenomas, and all patients were cured of PHPT following parathyroidectomy. Interestingly, previous reports mirror our observations that these lesions often are large, in relation to their sizes biochemically fairly indolent, and indecisively localised using scintigraphy, providing correlations of possible clinical value when pre-operatively assessing these rare lesions.
\end{abstract}

Key words: Primary hyperparathyroidism; water clear cell; adenoma; hyperplasia.

Received 2 December 2020, revised 11 February, accepted 16 February 2021 Available online 14 May 2021

\section{INTRODUCTION}

Although conventional chief cell or oncocytic adenomas constitute the majority of hyperfunctioning parathyroid glands encountered in the clinical setting, rare histological variants such as parathyroid lipoadenomas (PLAs) and water clear cell adenomas (WCCAs) exist. ${ }^{1}$ Around 90 cases of PLA have been previously described as causative of primary hyperparathyroidism (PHPT) in the literature, ${ }^{2,3}$ but significantly fewer WCCAs have been reported, making the latter entity the most unusual histological variant in terms of parathyroid neoplasia. $^{4-23}$ Moreover, rare descriptions of a predominant water clear cell morphology in PHPT patients with four-gland disease also exist, entitled water clear cell hyperplasia $(\mathrm{WCCH}){ }^{24}$ Although previously quite frequently described, this latter entity is now declining in incidence. ${ }^{25}$

From a historical perspective, WCCH preceded WCCA in terms of clinical descriptions, and the first case was published in $1934 .^{26} \mathrm{WCCH}$ does not show the same association with multiple endocrine neoplasia type 1 (MEN1) syndrome as conventional multiglandular disease in the PHPT setting (formerly described as 'primary hyperplasia'), but WCCH patients are nevertheless at risk of recurrent or persistent hypercalcaemia if a focused parathyroidectomy is performed rather than a bilateral neck exploration. ${ }^{27,28}$ The underlying genetic aberrancies in WCCH are not known, but the association with PHPT and the absence of chronic renal failure in this patient category would argue for a neoplastic susceptibility of some sort. WCCAs on the other hand are usually single lesions, and patients are regularly cured by a focused surgical approach in which the affected gland is excised. However, rare reports of double WCCAs have been reported, thereby somewhat blurring the line between WCCAs and WCCHs, and whether these patients are part of a continuous spectrum of PHPT with metachronous presentation is not known. ${ }^{8,21}$ Most patients with WCCAs or WCCHs exhibit mild hyperparathyroidism, and development of parathyroid carcinoma in this setting has only been reported once, suggesting that these lesions are almost always benign. ${ }^{29}$ Even though an eventual coupling to other intrinsic or extrinsic factors has not been established, rare WCCA cases 
have been reported in patients with underlying MEN1 and neurofibromatosis 1 (NF1) syndromes. ${ }^{4,11}$

From a histological perspective, WCCAs and WCCHs seem to exhibit identical morphological attributes, most notably cells arranged in cords or sheets exhibiting distinct cell borders with a finely reticulated pattern on low power magnification. ${ }^{1,14,25}$ The cytoplasm is dilated and filled with vacuoles, whereas the nuclei are hyperchromatic and often orientated in the basal aspect of the cell. The stromal fat content is heavily reduced or absent, and a normal rim of parathyroid tissue is often visualised in WCCAs, but not in WCCHs. The lesions stain positive for chromogranin A and $\mathrm{PTH}$, thereby suggesting that the water clear cells themselves are variants of parathyroid chief cells. Even though it may seem redundant given the PHPT setting, the endocrine pathologist should also be able to rule out the manifestation of unrelated tumours with clear cell morphology, such as clear cell variants of medullary or follicular thyroid carcinomas as well as metastatic clear cell renal cell carcinomas. ${ }^{1,14,25,30}$ Therefore, an immunohistochemical work-up with a panel consisting of PTH, TTF1 and CD10 should be recommended whenever a WCCA or WCCH is suspected. Moreover, the transcription factors GCM2 and GATA3 that synergistically influence PTH gene transcriptional output could also be considered in this aspect, as they are diffusely expressed in parathyroid cells and hence strongly argue in favour of a parathyroid origin. ${ }^{31-33}$

Given the general lack of descriptions in the scientific literature, we sought to determine the frequency of WCCAs and WCCHs diagnosed in our institution and to provide detailed histopathological and clinical information from this series. Moreover, a general literature search was performed to cover the current field, and to look for common denominators regarding this exceedingly rare PHPT subtype.

\section{MATERIALS AND METHODS}

Study cohort and case review

The Karolinska University Hospital in Stockholm, Sweden, is a tertiary centre for parathyroid surgery, with a catchment area of approximately 2.3 million inhabitants and about 200 parathyroidectomies performed annually. We screened our institutional electronic pathology database spanning 29 years (ranging from January 1992 to November 2020) for WCCAs and WCCHs diagnosed at the Karolinska University Hospital in Solna using an electronic search function using Systematized Nomenclature of Medicine (SNOMED) codes T97**** (for parathyroid) and M83220 (for WCCAs). External consultation cases were excluded to avoid referral bias. To detect WCCA cases erroneously SNOMED coded as conventional adenomas, as well as to highlight WCCHs across our database, we also screened the same pathology database for all diagnosed parathyroid glands using a dynamic search function including the term 'water', 'water clear' and 'water clear cell'. All cases (either coded as WCCA or with free text indicating a WCCA or WCCH in the pathology report) were subsequently reviewed in terms of histology to verify the diagnosis. The definition of WCCA is loosely defined by the most recent World Health Organization (WHO) classification as exceptionally rare tumours composed of cells with clear cytoplasm containing multiple small vacuoles, with small and hyperchromatic nuclei located in the centre or periphery of the cells. ${ }^{1}$ We expanded this definition to only include cases with one or two affected glands, to differentiate this entity from water clear cell hyperplasia $(\mathrm{WCCH})$, the latter entity defined as multiglandular disease (usually all four glands) with a clear-cell presentation on histology. We also looked specifically for signs of atypia (marked pleomorphism, mitoses, necrosis, fibrosis and equivocal relations to the surrounding capsule), the presence of an eventual normal parathyroid remnant and reviewed any eventual immunohistochemical stainings performed at the time of diagnosis. We also retrieved tissue blocks from the pathology archives and analysed them using immunohistochemistry to make all our institutional WCCAs and one gland from the sole WCCH informative in terms of PTH, GATA3, TTF1, monoclonal PAX8, calcitonin, CD10, parafibromin, APC and Ki-67 expression. All immunohistochemical stainings were procured via clinical routine practice using standardised protocols and an automated Ventana technology. The local ethics committee at Karolinska Institutet granted ethical approval, and informed consent was retrieved from patients prior to surgery.

\section{Clinical characteristics and patient follow-up}

Relevant clinical parameters were subsequently retrieved by accessing the patients' medical records. More specifically, information was recorded regarding age at surgery, patient sex, biochemistry (pre- and post-operative serum calcium and PTH levels), pre-operative symptoms, previous information of nephrolithiasis or bone disease, uniglandular/multiglandular disease, smoking habits and other diseases of interest. Outcomes measured were resolution of PHPT or persistent/recurrent hypercalcaemia. The National Population Register was also consulted (accessed November 2020) to find if the patients were still alive and, if applicable, the date of death.

\section{General PHPT cohort}

In order to compare the clinical parameters of our study cohort with conventional cases, we retrieved clinical characteristics from an independent clinical cohort consisting of 2504 cases of primary hyperparathyroidism (PHPT) treated at our institution between January 2008 and December 2017 (termed 'general PHPT cohort'). This series is retrieved from the Scandinavian Quality Register for Thyroid, Parathyroid and Adrenal Surgery (SQRTPA), the Swedish national quality registry for these tumours. For the PTH analyses, a previously published subgroup of 128 patients were used. ${ }^{34}$

\section{Statistics}

Due to the limited number of cases, descriptive statistics were mainly used. Continuous variables were reported as mean/median and range, and categorical variables as numbers with the occasional addition of percentages. By utilising the SPSS Statistics 24 software (IBM, USA), a Fisher's exact test was used to evaluate the difference in pre-operative localisation using ultrasound and scintigraphy, and a $p$ value $<0.05$ was considered statistically significant.

\section{RESULTS}

\section{Study cohort}

We identified a total of seven patients with pathological parathyroid glands of water clear cell morphology; six resected single WCCAs from six patients (Cases 1-6), and four pathological glands (of which 3.5 were resected) from a single patient with WCCH (Case 7). As approximately 4000 parathyroid surgeries had been performed at the Department during the same time interval, this corresponded to an institutional prevalence of $0.15 \%$ for WCCA and $0.025 \%$ for $\mathrm{WCCH}$.

\section{Histological characteristics}

The overall histopathological and immunohistochemical characteristics of the institutional water clear cell parathyroid lesions are outlined in Table 1 and illustrated in Fig. 1 and 2. The histological appearance of the cohort was homogenous. The vast majority of lesions did exhibit a cord-like growth pattern, with cells demonstrating a vacuolised cytoplasm and a marginalised nucleus (Fig. 1A,B). The stromal fat content was entirely depleted for most WCCA cases, and a normal rim of parathyroid tissue was often (but not always) seen (Fig. 1C,D and 2A). Nuclear pleomorphism (defined as an evident variation in nuclear shape, size and chromatin appearance) was only seen in a single WCCA, as well as in two of four WCCH glands (Fig. 2B). Mitoses, necrosis, fibrosis and equivocal relations to the surrounding capsule 
were not noted in any case. Immunohistochemical analyses verified a parathyroid origin (positive for PTH and GATA3 all cases, while consistently negative for TTF1, monoclonal PAX8, CD10 and calcitonin) (Fig. 2C,D, Table 1). The Ki-67 proliferation index was generally low, ranging from $<1 \%$ to $2 \%$, and all cases were diffusely positive for parafibromin and APC, suggesting that these cases lacked malignant potential as well as underlying $C D C 73$ gene mutations (Fig. 2E).

\section{Coupling to clinical parameters}

The clinical parameters of the afflicted patients are detailed in Table 2. All WCCA patients were female, while the sole $\mathrm{WCCH}$ case was male. The median age at surgery for all cases was 53 years (range 38-78). Biochemically, the median preoperative ionised calcium levels for informative cases was $1.40 \mathrm{mmol} / \mathrm{L}$ (range 1.37-1.65, reference 1.02-1.31), while the median PTH level was $17 \mathrm{pmol} / \mathrm{L}$ (range 9-21, reference 1.6-6.0), suggesting fairly mild biochemical disturbances in general.

Pre-operative localisation was performed using sestamibi scintigraphy in five cases (4 WCCAs and $1 \mathrm{WCCH}$ ), in which a conclusive finding was made in a single case $(20 \%)$, and the remaining cases were inconclusive $(n=3,60 \%)$ or false negative $(n=1,20 \%)$. Notably, three of four WCCAs assessed $(75 \%)$ were pre-operatively determined as inconclusive by sestamibi scintigraphy, and the only WCCH case was falsely believed to be a localised adenoma both by scintigraphy and neck ultrasound. Neck ultrasound was performed for all seven cases, in which a conclusive finding was made in five cases $(71 \%)$, and the remaining two cases $(29 \%)$ were either inconclusive (1 WCCA) or falsely negative (the sole WCCH case).

Surgically, the WCCA patients predominantly underwent bilateral exploration of all four glands $(n=4$, including all 3 cases with indecisive pre-operative sestamibi scintigraphy), and only two patients were treated with a focused, unilateral approach. The median weight of WCCAs was $730 \mathrm{mg}$ (range 470-3480), with a mean of $1215 \mathrm{mg}$, which indicates that these tumours are considerably larger than conventional adenomas, in which tumour weights $<1 \mathrm{~g}$ are regularly reported. The sole WCCH patient underwent bilateral neck exploration and intraoperative frozen sections, which verified the $\mathrm{WCCH}$ diagnosis; therefore, the surgeon decided for a subtotal parathyroidectomy.

Post-operatively, all seven patients (100\%) displayed resolved PHPT with normal post-operative biochemistry. No patients exhibited familial history indicative of PHPT, nor did any patient present with additional, unrelated tumours. All patients were alive at follow-up. Only one patient was an active smoker at time of surgery (Case 7).

\section{Comparisons to the general PHPT cohort}

The study cohort $(n=7)$ was fairly similar to the general PHPT cohort $(n=2504)$ in terms of age at surgery (mean 56 vs 61 years), gender distribution ( $86 \%$ vs $76 \%$ female), preoperative levels of ionised calcium (1.40 vs $1.45 \mathrm{mmol} / \mathrm{L})$ and PTH (17 vs $10 \mathrm{pmol} / \mathrm{L})$. The rate of persistent/recurrent PHPT in the WCC cohort was $0 \%$, compared to $4 \%$ in the general PHPT cohort. Regarding tumour weight, we excluded the sole $\mathrm{WCCH}$ case as this patient received a subtotal parathyroidectomy, and hence complete data 

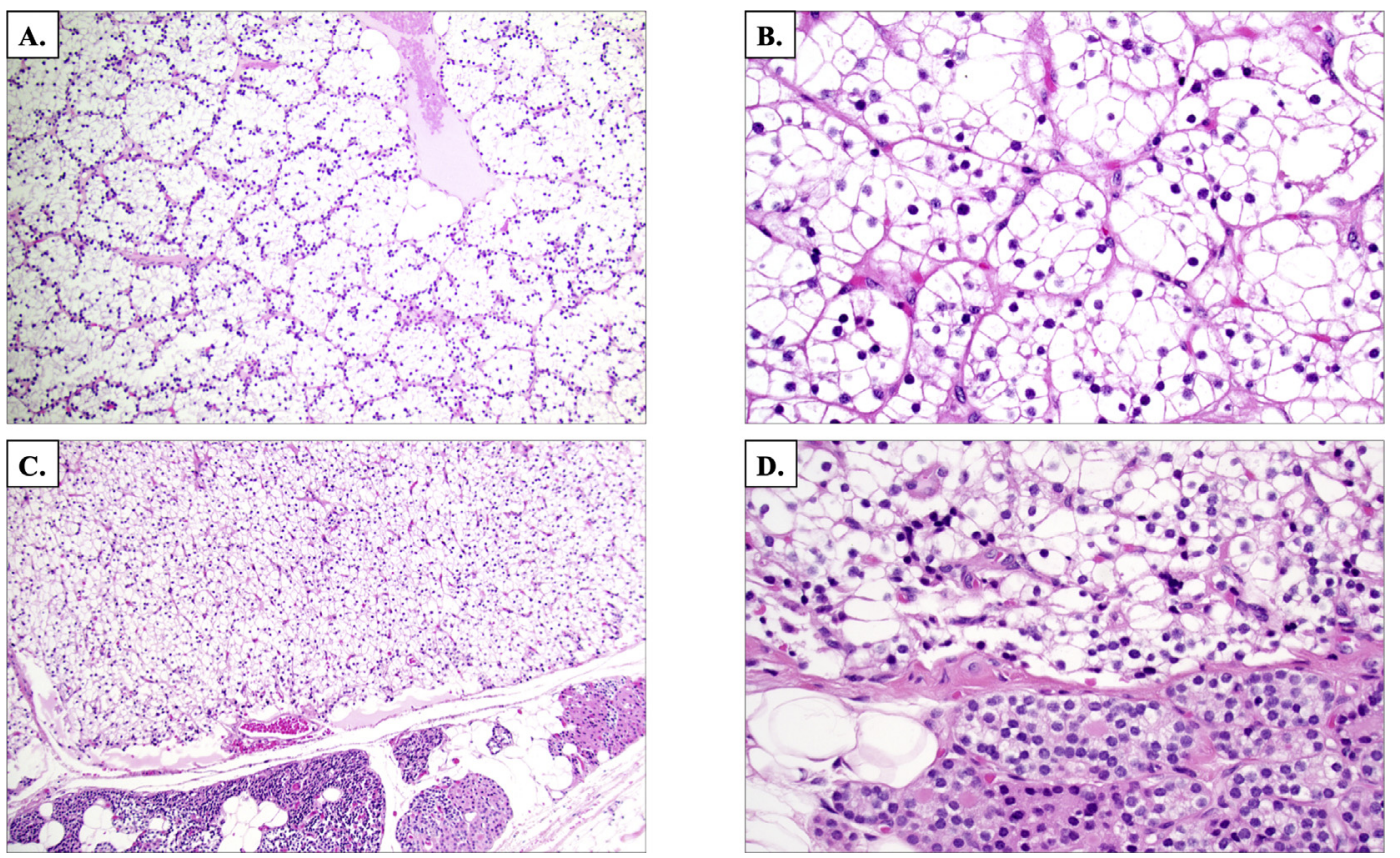

Fig. 1 Histological attributes of parathyroid water clear cell adenomas (WCCAs), routine H\&E stains. (A) Case 1 demonstrating cord-like arrangement of tumour cells with abundant water-clear cytoplasm and peripheral tumour nuclei without pleomorphic features. Note the absence of stromal fat. (B) Case 4 highlighting the delicate stroma surrounding the tumour cell nests. (C) Case 4 with a rim of normal parathyroid tissue in the bottom of the image. A normal rim was often present when reviewing the WCCAs. (D) Same case at higher magnification, emphasising the morphological differences between WCCAs and conventional parathyroid chief cells.
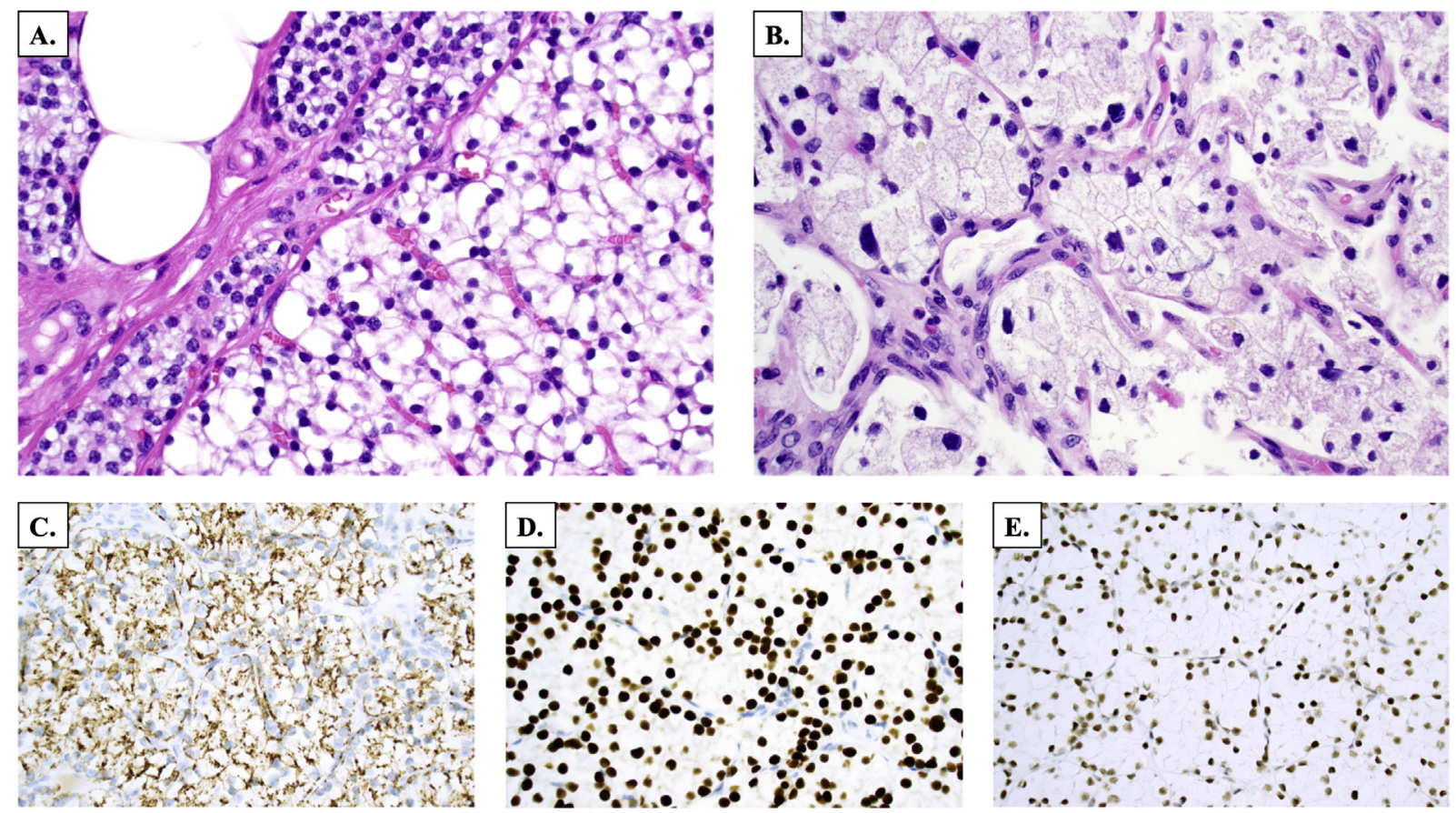

Fig. 2 Additional microscopic and immunohistochemical features of parathyroid water clear cell adenomas (WCCAs). (A) Case 5 highlighting the monomorphic appearance of the WCCA nuclei. Note the normal parathyroid remnant in the upper left corner. (B) Case 2 exhibiting nuclear pleomorphism. This was an unusual finding, without apparent correlation with patient outcome. (C-E) Immunohistochemical analyses of Case 1 showing diffusely positive PTH, GATA3 and parafibromin expression, respectively.

regarding the glandular weights was lacking. Interestingly, the WCCAs $(n=6)$ displayed a median weight of $730 \mathrm{mg}$, compared to $459 \mathrm{mg}$ in the general PHPT cohort. Even though our WCC series contains few cases, which precludes statistical analyses, these analyses might indicate a true overrepresentation of larger tumours in the WCCA cohort compared to the general PHPT population.

\section{Literature search}

After reviewing the PubMed/MEDLINE search engine and conducting separate searches using standard web browsers for journals not indexed in these databases, we found available and readable descriptions of 24 WCCAs up until November $2020 .^{4-23}$ These cases, including our six cases 
Table 2 Main clinical findings in the parathyroid water clear cell lesion cohort

\begin{tabular}{|c|c|c|c|c|c|c|c|c|c|c|c|c|c|c|}
\hline $\begin{array}{l}\text { Case } \\
\text { no. }\end{array}$ & $\begin{array}{l}\text { Age at } \\
\text { surgery }\end{array}$ & Sex & $\underset{(\mathrm{mmol} / \mathrm{L})}{\mathrm{Ca} 2+}$ & $\begin{array}{c}\mathrm{PTH} \\
(\mathrm{pmol} / \mathrm{L})\end{array}$ & HPT symptoms & Dx & $\begin{array}{l}\text { Affected } \\
\text { gland/s }\end{array}$ & $\begin{array}{l}\text { Tumour } \\
\text { weight } \\
(\mathrm{mg})\end{array}$ & $\begin{array}{l}\text { No of } \\
\text { glands } \\
\text { removed }\end{array}$ & Type of surgery & $\begin{array}{c}\text { Preoperative } \\
\text { localisation }\end{array}$ & $\begin{array}{l}\text { Persistent } \\
\text { or recurrent } \\
\text { HPT }\end{array}$ & $\begin{array}{c}\text { Follow-up } \\
\text { time, } \\
\text { months }\end{array}$ & Other diseases \\
\hline 1 & 53 & $\mathrm{~F}$ & 1.37 & 12 & $\begin{array}{l}\text { Asymptomatic, high } \\
\text { dU-Ca }\end{array}$ & WCCA & $\begin{array}{l}\text { Left } \\
\text { inferior }\end{array}$ & 538 & 1 & $\begin{array}{l}4 \text { gland neck } \\
\text { exploration }\end{array}$ & $\begin{array}{l}\text { Sestamibi } \\
\text { inconclusive, } \\
\text { US probably } \\
\text { conclusive }\end{array}$ & No & 8 & $\begin{array}{l}\text { Obesity (BMI 41.3), } \\
\text { DM2, HBP }\end{array}$ \\
\hline 2 & 78 & $\mathrm{~F}$ & 1.65 & 17 & Nephrolithiasis & WCCA & $\begin{array}{l}\text { Right } \\
\text { superior }\end{array}$ & 3480 & 1 & $\begin{array}{l}4 \text { gland neck } \\
\text { exploration }\end{array}$ & $\begin{array}{l}\text { Sestamibi } \\
\text { inconclusive, } \\
\text { US probably } \\
\text { conclusive }\end{array}$ & No & 24 & Multi-nodular goitre \\
\hline 3 & 52 & $\mathrm{~F}$ & 1.38 & 9 & $\begin{array}{l}\text { Psychological } \\
\text { NOS, muscle pain }\end{array}$ & WCCA & $\begin{array}{l}\text { Right } \\
\text { inferior }\end{array}$ & 470 & 1 & $\begin{array}{l}4 \text { gland neck } \\
\text { exploration }\end{array}$ & $\begin{array}{l}\text { Sestamibi and US } \\
\text { conclusive }\end{array}$ & No & 12 & Lichenoid dermatitis \\
\hline 4 & 38 & $\mathrm{~F}$ & 1.41 & 19 & $\begin{array}{l}\text { Fatigue, depression, } \\
\text { vertigo }\end{array}$ & WCCA & $\begin{array}{l}\text { Left } \\
\text { inferior }\end{array}$ & 1340 & 1 & Focused unilateral & $\begin{array}{l}\text { No sestamibi } \\
\text { performed, US } \\
\text { conclusive }\end{array}$ & No & 7 & No \\
\hline 5 & 61 & $\mathrm{~F}$ & 1.38 & 13 & $\begin{array}{l}\text { Osteopenia, } \\
\text { neuromuscular } \\
\text { symptoms, depression }\end{array}$ & WCCA & $\begin{array}{l}\text { Right } \\
\text { inferior }\end{array}$ & 883 & 1 & $\begin{array}{l}4 \text { gland neck } \\
\text { exploration }\end{array}$ & $\begin{array}{l}\text { Sestamibi and US } \\
\text { inconclusive }\end{array}$ & No & $<5$ & $\begin{array}{l}\text { Hypo-thyroidism, } \\
\text { HBP }\end{array}$ \\
\hline 6 & 58 & $\mathrm{~F}$ & 1.44 & 21 & $\begin{array}{l}\text { Osteopenia, fatigue, } \\
\text { muscle pain }\end{array}$ & WCCA & $\begin{array}{l}\text { Left } \\
\text { superior }\end{array}$ & 577 & 1 & Focused unilateral & $\begin{array}{l}\text { No sestamibi } \\
\text { performed, US } \\
\text { conclusive }\end{array}$ & No & $<5$ & No \\
\hline 7 & 50 & M & $2.93^{\mathrm{a}}$ & 20 & Nephrolithiasis & WCCH & All four & $\begin{array}{l}103,800 \\
60,1400\end{array}$ & 3.5 & $\begin{array}{l}\text { Subtotal } \\
\text { parathyroid- } \\
\text { ectomy }\end{array}$ & $\begin{array}{l}\text { Sestamibi and US } \\
\text { false negative }\end{array}$ & No & 13 years & HBP \\
\hline
\end{tabular}

BMI, body mass index; DM2, diabetes mellitus type 2; dU-Ca, daily urinary calcium; Dx, diagnosis; F, female; HBP, high blood pressure; HPT, hyperparathyroidism; WCCA, water clear cell adenoma; WCCH, water clear cell hyperplasia; M, male; NOS, not otherwise specified; US, ultrasound.

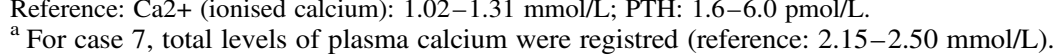


Table 3 Literature review of previously reported parathyroid water clear cell adenomas

\begin{tabular}{|c|c|c|c|c|c|c|c|c|}
\hline First author (publication year) & No. of patients & No. of tumours & Age at surgery & Sex & Tumour weight (mg) & Pre-operative ultrasound & Pre-operative scintigraphy ${ }^{\mathrm{a}}$ & Comments \\
\hline Kovacs (1994) & 1 & 1 & 48 & M & $\mathrm{Nr}$ & $\mathrm{Nr}$ & $\mathrm{Nr}$ & Patient with MEN1 syndrome \\
\hline Grenko (1995) & 1 & 1 & 40 & $\mathrm{M}$ & 7600 & NV & NV & \\
\hline Begueret (1999) & 1 & 1 & 73 & $\mathrm{M}$ & $\mathrm{Nr}$ & $\mathrm{Na}$ & $\mathrm{Na}$ & \\
\hline Dundar (2001) & 1 & 1 & 43 & $\mathrm{~F}$ & $\mathrm{Nr}$ & $\mathrm{v}$ & $\mathrm{Nr}$ & Thyroid scintigraphy negative \\
\hline Kuhel (2001) & 1 & 2 & 56 & F & 1700 and 500 & $\mathrm{Na} / \mathrm{Na}$ & $\mathrm{NV} / \mathrm{NV}$ & $\begin{array}{l}\text { Double tumours in a single } \\
\text { patient }\end{array}$ \\
\hline Kanda (2004) & 1 & 1 & 52 & F & 15400 & $\mathrm{~V}$ & $\mathrm{~V}(\mathrm{TITc})$ & \\
\hline Prasad (2004) & 1 & 1 & 40 & F & 4200 & $\mathrm{Nr}$ & $\mathrm{Nr}$ & \\
\hline Kodama (2007) & 1 & 1 & 18 & $\mathrm{~F}$ & 21700 & $\mathrm{~V}$ & $\mathrm{~V}(\mathrm{TITc})$ & Patient with NF1 syndrome \\
\hline Liang (2010) & 1 & 1 & 59 & $\mathrm{~F}$ & & $\mathrm{Nr}$ & Inconclusive $^{b}$ & $\begin{array}{l}\text { First scintigraphy false } \\
\text { negative, positive upon } \\
\text { repeat investigation }\end{array}$ \\
\hline Papanicolau-Sengos (2011) & 1 & 1 & 64 & $\mathrm{M}$ & $\mathrm{Nr}$ & $\mathrm{Nr}$ & $\mathrm{Nr}$ & Patient with HIV infection \\
\hline Bai (2012) & 2 & 2 & $81 / 55$ & $\mathrm{M} / \mathrm{M}$ & $6910 / 270$ & $\mathrm{NV} / \mathrm{NV}$ & $\mathrm{V} / \mathrm{NV}$ & \\
\hline Piggot (2013) & 1 & 1 & 74 & $\mathrm{~F}$ & 13000 & $\mathrm{~V}$ & $\mathrm{~V}$ & \\
\hline Ezzat (2013) & 2 & 2 & $73 / 74$ & $\mathrm{M} / \mathrm{F}$ & $8000 / 900$ & $\mathrm{~V} / \mathrm{V}$ & $\mathrm{V} / \mathrm{NV}$ & \\
\hline Chou (2014) & 1 & 1 & 81 & $\mathrm{~F}$ & $\mathrm{Nr}$ & $\mathrm{V}$ & $\mathrm{V}$ & \\
\hline Tassone (2014) & 1 & 1 & 54 & F & $\mathrm{Nr}$ & $\mathrm{V}$ & $\mathrm{V}$ & \\
\hline Murakami (2014) & 1 & 1 & 59 & $\mathrm{~F}$ & 500 & $\mathrm{~V}$ & $\mathrm{NV}$ & \\
\hline Pirela (2016) & 1 & 1 & 34 & F & $\mathrm{Nr}$ & $\mathrm{V}$ & $\mathrm{Nr}$ & Intrathyroidal tumour \\
\hline Yazar (2017) & 1 & 2 & 47 & $\mathrm{M}$ & 1900/900 & $\mathrm{V} / \mathrm{V}$ & $\mathrm{NV} / \mathrm{NV}$ & Mediastinal double tumours \\
\hline Arik (2019) & 1 & 1 & 70 & M & $\mathrm{Nr}$ & $\mathrm{Nr}$ & $\mathrm{Nr}$ & Mediastinal tumour \\
\hline Zinovkin (2020) & 1 & 1 & 64 & $\mathrm{~F}$ & 5340 & $\mathrm{Nr}$ & $\mathrm{Nr}$ & \\
\hline Juhlin (2021) & 6 & 6 & $\begin{array}{l}53 / 78 / 52 / \\
38 / 61 / 58\end{array}$ & $\mathrm{~F} \times 6$ & $\begin{array}{l}538 / 3480 / 470 / \\
1340 / 883 / 577\end{array}$ & $\begin{array}{l}\mathrm{V} / \mathrm{V} / \mathrm{V} / \\
\mathrm{V} / \mathrm{NV} / \mathrm{V}\end{array}$ & $\begin{array}{l}\mathrm{NV} / \mathrm{NV} / \mathrm{V} / \\
\mathrm{Nr} / \mathrm{NV} / \mathrm{Nr}\end{array}$ & Current study \\
\hline Total & 28 & 30 & Mean 57 & F:M 19:9 & Median 1700 & V 17/21 (81\%) & V 8/19 (42\%) & \\
\hline
\end{tabular}

F, female; M, male; $\mathrm{Na}$, (information) not available; $\mathrm{Nr}$, not reported; $\mathrm{NV}$, not visualised; TITc, tallium technetium subtraction scintigraphy; V, visualised.

${ }^{a}$ Sestamibi scintigraphy if not otherwise reported.

${ }^{b}$ Counted as 'not visualised'. 
reported herein, are briefly summarised in Table 3 along with some baseline clinical characteristics. From the current literature, it seems evident that the majority of WCCA cases published are large tumours arising predominantly in female patients exhibiting classical features of PHPT. The preoperative localisation was often indecisive using sestamibi or tallium technetium subtraction scintigraphy (inconclusive or negative in 11 of 19 cases, 58\%) compared to neck ultrasound examinations (negative in 4 of 21 cases, 19\%) (Fisher's exact $p=0.0211$ ). Moreover, the subsequent surgical excision often led to the reversion of hypercalcaemia and/or elevated PTH levels. A single case with malignant features (vascular invasion) has been described, thereby constituting the only known description of a water clear cell carcinoma of the parathyroid gland. ${ }^{29}$ The remaining cases have all exhibited benign clinical courses.

\section{DISCUSSION}

Although the vast majority of parathyroid adenomas are built-up by conventional chief cells or oxyphilic cells, practicing endocrine pathologists occasionally stumble across rare histological variants that mandate additional considerations, such as cystic adenomas, lipoadenomas and WCCAs. As these lesions are so rarely encountered in the clinical setting, it should come as no surprise that detailed descriptions exist only as scattered case reports and occasional case series. Consequently, potentially relevant associations to underlying genetics or unrelated clinical parameters might be overlooked. For example, our previous observation that subsets of cystic parathyroid adenomas with a benign clinical course display negative parafibromin staining due to underlying somatic $C D C 73$ gene mutations has increased our awareness that not all $C D C 73$ mutated parathyroid tumours display malignant potential. ${ }^{35}$ Similarly, we have shown that patients with parathyroid lipoadenomas demonstrate an association with arterial hypertension, which might be an important clinical clue worthwhile of further scientific investigations, and might also instigate blood pressure screening of individual patients diagnosed with this rare adenoma subtype. ${ }^{2}$ In addition, here we present the hitherto largest cohort of WCCAs, allowing us to describe the histological and immunohistochemical attributes of this exceedingly rare tumour, as well as to identify a potential association with decreased sensitivity regarding pre-operative scintigraphic localisation.

The aetiology of WCCAs is largely unknown. Although single cases have been reported in patients with MEN1 and NF1, respectively, no pathogenic somatic mutations have been described for this entity. ${ }^{4,11}$ Although molecular analyses would potentially enhance the impact of our study, we reluctantly had to refrain from such laboratory investigations due to the general lack of fresh-frozen tumour and constitutional tissues. However, we do know that all WCCAs in our cohort exhibited diffuse nuclear expression of parafibromin, thereby diminishing the likelihood of underlying $C D C 73$ gene mutations and malignant potential in these tumours. ${ }^{36,37}$ At least two other WCCAs known in the literature have been similarly investigated for parafibromin expression, both with positive immunoreactivity. ${ }^{14}$ Based on the results from our cohort as well as previously published cases, WCCAs are also regularly positive for PTH and GATA3 immunoreactivity, thereby verifying these lesions as parathyroid-derived. ${ }^{6-8,14}$ This is important information for the practicing endocrine pathologist, as historical mimics such as the clear cell variants of follicular thyroid carcinoma (FTC) and medullary thyroid carcinoma (MTC) exist, in addition to rare cases of paragangliomas and metastatic clear-cell renal cell carcinomas.

By reviewing the current literature, we identified a total of 24 previously published WCCAs with credible descriptions in peer reviewed journals. Although the amount of retrievable histological and clinical information varied across the study pool, we were able to conclude that WCCAs are benign tumours, and biochemically quite indolent despite their large sizes. Moreover, a significant subset of cases was not correctly localised pre-operatively using scintigraphy imaging. As the majority of our institutional WCCAs also were large, fairly biochemically idle, and often inconclusive in terms of localisation using scintigraphy, our observations from previous studies mirror the findings from our own series. In previous functional experiments using a senescence-accelerated mouse model, the number of water clear cells in normal parathyroid glands increased, suggesting a correlation with aging. ${ }^{38}$ However, our data indicate that WCCA patients exhibit a similar age span as patients with conventional adenomas.

The WCCAs identified in this study were all relatively large and, on the basis of previously reported institutional experience, should have been detected by Tc-99m sestamibi scintigraphy. ${ }^{39}$ This pre-operative localisation method of parathyroid adenomas is considered a gold-standard technique and a positive scintigram correlates with larger tumours and patients with higher pre-operative serum calcium levels. ${ }^{40,41}$ Following radiotracer injection, images are regularly taken at separate time intervals, and adenomas are usually visualised due to much slower wash-out compared to the thyroid gland, an attribute which might be due to the ability of sestamibi to aggregate in mitochondria and the mitochondria-rich cytoplasm of scattered oxyphilic cells found in many conventional adenomas. ${ }^{42}$ As WCCAs are biochemically placid and display a vacuolised, glycogen-rich cytoplasm with little or no mitochondria, this could potentially explain a fast sestamibi wash-out and hence false negative imaging results. ${ }^{5}$ Indeed, ultrastructural investigations of water clear cells indicate that the observed vacuoles could be either dilated Golgi or endoplasmic reticulum structures, but whether or not these aberrant assemblies can affect the ability to retain sestamibi remains to be proven. ${ }^{43}$ Furthermore, our data indicate that neck ultrasound was more reliable in the context of pre-operative localisation of WCCAs, which is not surprising given the cytoplasmic ballooning of cells, giving rise to a large adenoma with excessive water content.

\section{CONCLUSIONS}

To summarise, we present the largest single-institution cohort of WCCAs to date, and conclude that these lesions are generally large, biochemically fairly indolent, lowproliferative and benign neoplasms that often escape detection using sestamibi scintigraphy. Further molecular studies might help identify the genetic drivers of this morphologically and clinically distinct PHPT subtype.

Acknowledgements: The authors wish to thank Ms Lisa Ånfalk, biomedical scientist, for superb tissue handling. 
Conflicts of interest and sources of funding: This work was supported by the Swedish Cancer Society. The authors state that there are no conflicts of interest to disclose.

Address for correspondence: A/Prof Dr C. Christofer Juhlin, Department of Oncology-Pathology, BioClinicum J6:20, Karolinska Institutet, 17164 Solna, Sweden. E-mail: christofer.juhlin@ki.se

\section{References}

1. Lloyd RV, Osamura RY, Klöppel G, Rosai J, editors. WHO Classification of Tumours of Endocrine Organs. 4th ed. Lyon: IARC, 2017; 355 .

2. Juhlin CC, Falhammar H, Zedenius J, Nilsson I-L, Höög A. Lipoadenoma of the parathyroid gland: characterization of an institutional series spanning 28 years. Endocr Pathol 2020; 31: 156-65.

3. Hyrcza MD, Sargin P, Mete O. Parathyroid lipoadenoma: a clinicopathological diagnosis and possible trap for the unaware pathologist. Endocr Pathol 2016; 27: 34-41.

4. Kovacs K, Horvath E, Ozawa Y, Yamada S, Matushita H. Large clear cell adenoma of the parathyroid in a patient with MEN-1 syndrome. Ultrastructural study of the tumour exhibiting unusual RER formations. Acta Biol Hung 1994; 45: 275-84.

5. Grenko RT, Anderson KM, Kauffman G, Abt AB. Water-clear cell adenoma of the parathyroid. A case report with immunohistochemistry and electron microscopy. Arch Pathol Lab Med 1995; 119: 1072-4.

6. Bégueret H, Belleannée G, Dubrez J, et al. Clear cell adenoma of the parathyroid gland: a rare and misleading lesion. Ann Pathol 1999; 19: 316-9.

7. Dundar E, Grenko RT, Akalin A, Karahuseyinoglu E, Bildirici K. Intrathyroidal water-clear cell parathyroid adenoma: a case report. Hum Pathol 2001; 32: 889-92.

8. Kuhel WI, Gonzales D, Hoda SA, et al. Synchronous water-clear cell double parathyroid adenomas a hitherto uncharacterized entity? Arch Pathol Lab Med 2001; 125: 256-9.

9. Kanda K, Okada Y, Tanikawa T, et al. A rare case of primary hyperparathyroidism with clear cell adenoma. Endocr J 2004: 51: 207-12.

10. Prasad KK, Agarwal G, Krishnani N. Water-clear cell adenoma of the parathyroid gland: a rare entity. Indian J Pathol Microbiol 2004; 47: 39-40.

11. Kodama H, Iihara M, Okamoto T, Obara T. Water-clear cell parathyroic adenoma causing primary hyperparathyroidism in a patient with neurofibromatosis type 1: report of a case. Surg Today 2007; 37: 884-7.

12. Liang Y, Wilfrido M, Chen F. Water-clear cell adenoma of parathyroid gland: a case report and literature review. North Am J Med Sci 2010; 3: 194-8.

13. Papanicolau-Sengos A, Brumund K, Lin G, Hasteh F. Cytologic findings of a clear cell parathyroid lesion. Diagn Cytopathol 2013; 41 $725-8$.

14. Bai S, LiVolsi VA, Fraker DL, Bing Z. Water-clear parathyroid adenoma: report of two cases and literature review. Endocr Pathol 2012; 23: $196-200$.

15. Piggott RP, Waters PS, Ashraf J, Colesky F, Kerin MJ. Water-clear cell adenoma: a rare form of hyperparathyroidism. Int J Surg Case Rep 2013; 4: $911-3$.

16. Ezzat T, Maclean GM, Parameswaran R, et al. Primary hyperparathyroidism with water clear cell content: the impact of histological diagnosis on clinical management and outcome. Ann R Coll Surg Engl 2013; 95: e60-2.

17. Chou Y-H, Jhuang J-Y, Hsieh M-S. Water-clear cell parathyroid adenoma in a patient with acute pancreatitis. J Formos Med Assoc 2014; 113: $872-3$.

18. Tassone P, Kaplan S, Kenyon L, Rosen D, Pribitkin E. Water clear cell parathyroid adenoma: case report and literature review. J Thyroid Disord Ther 2014; 3: 1-4.

19. Murakami K, Watanabe M, Nakashima N, et al. Water-clear cell adenoma associated with primary hyperparathyroidism: report of a case. Surg Today 2014; 44: 773-7.

20. Pirela D, Treitl D, El Hussein S, Poppiti R, Mesko T, Manzano A. Intrathyroidal clear cell tumor of parathyroid origin with review of literature. Case Rep Pathol 2016; 2016: 7169564.
21. Yazar FM, Karaağaç M, İşler A, Bülbüloğlu E, Ezberci F. An unusua cause of hypercalcemic crisis: water-clear cell double parathyroid adenoma. Turk J Surg 2017; 33: 243-7.

22. Arik D, Dündar E, Yilmaz E, Sivrikoz C. Water-clear cell adenoma of the mediastinal parathyroid gland. Turk Patoloji Derg 2019; 35: $157-61$.

23. Zinovkin DA, Zhandarov MY, Pranjol MZI. Water clear cell adenoma of parathyroid gland: a rare lesion. Exp Oncol 2020; 42: 248.

24. Tisell LE, Hedman I, Hansson G. Clinical characteristics and surgical results in hyperparathyroidism caused by water-clear cell hyperplasia. World J Surg 1981; 5: 565-71.

25. El Hussein S, Poppiti R. Water clear cell adenoma of the parathyroid gland: a forgotten cause of primary hyperparathyroidism. Int J Surg Pathol 2017; 25: 384-8.

26. Albright F, Bloomberg E, Castleman B, Churchill ED. Hyperparathyroidism due to diffuse hyperplasia of all parathyroid glands rather than adenoma of one: clinical studies on three such cases. Arch Intern Med 1934; 54: 315-29.

27. Castleman B, Schantz A, Roth S. Parathyroid hyperplasia in primary hyperparathyroidism: a review of 85 cases. Cancer 1976; 38: 1668-75.

28. Dawkins RL, Tashjian AH, Castleman B, Moore EW. Hyperparathyroidism due to clear cell hyperplasia. Serial determinations of serum ionized calcium, parathyroid hormone and calcitonin. Am J Med 1973; 54: $119-26$

29. Naganuma H, Shibuya R, Takaya K, Asakura T, Mori Y, Kameyama K. Water-clear cell carcinoma of parathyroid gland with primary hyperparathyroidism: first case report with review of the literature. $J$ Basic Clin Med 2013; 2: 7-9.

30. Juhlin CC, Bränström R, Shabo I, Höög A. Clear cell variant of a follicular thyroid tumor with uncertain malignant potential: a case report. Int J Surg Pathol 2018; 29: 1066896918809490.

31. Han S-I, Tsunekage Y, Kataoka K. Gata3 cooperates with $\mathrm{Gcm} 2$ and MafB to activate parathyroid hormone gene expression by interacting with SP1. Mol Cell Endocrinol 2015; 411: 113-20.

32. Naveh-Many T, Silver J. Transcription factors that determine parathyroid development power PTH expression. Kidney Int 2018; 93: 7-9.

33. Juhlin CC, Erickson LA. Genomics and epigenomics in parathyroid neoplasia: from bench to surgical pathology practice. Endocr Pathol 2021; 32: 17-34.

34. Koman A, Ohlsson S, Bränström R, Pernow Y, Bränström R, Nilsson IL. Short-term medical treatment of hypercalcaemia in primary hyperparathyroidism predicts symptomatic response after parathyroidectomy. Br J Surg 2019; 106: 1810-8.

35. Juhlin C, Larsson C, Yakoleva $\mathrm{T}$, et al. Loss of parafibromin expression in a subset of parathyroid adenomas. Endocr Relat Cancer 2006; 13: $509-23$.

36. Gill AJ, Lim G, Cheung VKY, et al. Parafibromin-deficient (HPT-JT Type, CDC73 mutated) parathyroid tumors demonstrate distinctive morphologic features. Am J Surg Pathol 2019; 43: 35-46.

37. Juhlin CC, Nilsson I-L, Lagerstedt-Robinson K, et al. Parafibromin immunostainings of parathyroid tumors in clinical routine: a near-decade experience from a tertiary center. Mod Pathol 2019; 32: 1082-94.

38. Chen H, Emura S, Shoumura S. Ultrastructure of the water-clear cell in the parathyroid gland of SAMP6 mice. Tissue Cell 2006; 38: 187-92.

39. Sandqvist P, Nilsson I-L, Grybäck P, Sanchez-Crespo A, Sundin A SPECT/CT's advantage for preoperative localization of small parathyroid adenomas in primary hyperparathyroidism. Clin Nucl Med 2017; 42: e109-14.

40. Itani M, Middleton WD. Parathyroid imaging. Radiol Clin North Am 2020; 58: 1071-83.

41. Çayir D, Araz M, Yalçindağ A, Çakal E. The relationship between semiquantitative parameters derived from technetium-99m metoxyisobutylisonitrile dual-phase parathyroid single-photon emission computed tomography images and disease severity in primary hyperparathyroidism. Nucl Med Commun 2018; 39: 304-11.

42. Cordes M, Dworak O, Papadopoulos T, Coerper S, Kuwert T. MIBI scintigraphy of parathyroid adenomas: correlation with biochemical and histological markers. Endocr Res 2018; 43: 141-8.

43. Roth SI. The ultrastructure of primary water-clear cell hyperplasia of the parathyroid glands. Am J Pathol 1970; 61: 233-48. 